\title{
Bronwyn Bailey-Charteris
}

\section{REVEALING THE HYDROCENE: REFLECTIONS ON WATERY RESEARCH}

\begin{abstract}
This reflective paper shares considerations of curatorial research of art and water during the current climate crises as part of both contemporary art and Blue Humanities fields. This paper shares water-based methods utilised to develop the Hydrocene, the water-based curatorial theory I have named and defined as an act of curatorial planetary caretaking. In my doctoral thesis, Ingesting the Hydrocene, I argue that water, this most vital of materials, is the central figure of the climate crisis and that a zeitgeist of groundbreaking artists cultivate critical and collaborative methods of relating with water from which we must learn. The Hydrocene as a curatorial theory reveals hitherto unexamined curatorial perspectives on the interrelation of art and water in acts of planetary climate care. The act of naming and defining this artistic tide as the Hydrocene, is a curatorial act of caretaking returning to the epistemological origins of the curator as caretaker. The flow-on effect of the art of the Hydrocene is the potential for more radical ways of relating to water ethically.

Sharing the Hydrocene and the complexities of a sustained dedication to learning from and with water in the field of art, this paper aims to illuminate the way water offers intellectual, emotional, physical and metaphorical sustenance to myself and the artists I work with. In return for this wealth of knowledge from water, I aim to recognize waters own agency, power and adaptability, and to enter into principled collaborations with it.
\end{abstract}

Keywords: hydrocene, curating, curatorial theory, art, climate crisis, water, blue humanities, thinking with water, hydrofeminism

This reflective paper shares considerations of curatorial research of art and water during the current climate crises as part of both the Blue Humanities and contemporary art fields. This paper shares water-based methods utilised to develop the Hydrocene, the water-based curatorial theory I have named and defined as an act of curatorial planetary caretaking. In my doctoral thesis, Ingesting the
Hydrocene, I argue that water, this most vital of materials, is the central figure of the age of the climate crisis and a zeitgeist of groundbreaking artists cultivate critical and collaborative methods of relating with water from which we must learn. The flow-on effect of the art of the Hydrocene is the potential for more radical ways of relating to water ethically. 
Sharing the Hydrocene and the complexities of a sustained dedication to learning from and with water in the field of art, this paper aims to illuminate the way water offers intellectual, emotional, physical and metaphorical sustenance to myself and the artists I work with. In return for this wealth of knowledge from water, I aim to recognize waters own agency, power and adaptability, and to enter into principled collaborations with it.

\section{Staying with the Water}

I believe that art has a huge role to play in the cultural climate crisis. Beyond data and measurements, the climate crisis is a crisis of both ecological destruction and dwindling poetic imagination. Some artists cultivate ways of knowing, being and doing that run counter-clockwise to the dominant ideas of society. Since 2003, when I first began engaging myself in contemporary artistic practices, I have continually been impressed by the way artists overcome problems: large, small and seemingly unpassable. Artistic approaches to problems often begin with an acknowledgement that the world is a place of uncertainty, and the artists whom I work with tend to "stay with the trouble," an important call to action from Donna Haraway. Artists exist with difficult, troubled, unfinished fragments and in this mess, some artists are able to create versions of reality that are multilayered, delicate and challenging. These methods of artistic practice are beyond necessary for the current reckoning of our species.
The artists who I see that are "staying with the trouble"1 are not simply presenting about global warming or plastics in the ocean, but instead these artists are diving in deep, working actively towards climate solutions and getting their hands dirty. In the Nordic region artist collectives are leading the way in many of the eco-aesthetic conversations, doing remarkable work with ecology and climate as fundamentally a question of reimagining ways of living. In Northern Finland the no-fly collective Mustarinda run residences around post-fossil fuel culture. In the Swedish town Gnesta, experimental art collective Art Lab Gnesta illuminate interspecies artistic and activist practices. Further south on the Swedish island of Öland, artist and agriculture collective Kultivator delve into multispecies collaborative projects. In Denmark the curatorial collective Laboratory for Aesthetics and Ecology curate and publish about the borders of the non-human and collective practice. These artists, curators and collectives bring poetry and politics together in a highly embodied way, often through connection to site and community.

\section{Hydrocene as a curatorial theory}

The curatorial has an important role to play in this current climate crisis and I believe the curator must become a planetary caretaker. Drawing on Haraway's term of cultivating "response-ability,"

D.J. Haraway, Staying with the Trouble: Making Kin in the Chthulucene, Duke University Press, Durham 2016. 
I extend this important term into an art context by saying that the curatorial now operates in the midst of a global climate crisis, and therefore must develop response-ability to both the artists and their work, and to the climate crisis and the dying planet. The curatorial has a responsibility to think and perform on a planetary scale to meet the challenges of a planetary crisis. In this way the curatorial becomes all at once a bridge builder, a community maker, a connector and a defining force for planetary caretaking. It is important to note here that the curatorial is often performed by curators, but also artists, writers, theorists, other cultural workers and more. The curatorial as planetary agent of care is a state of being, and a methodology for participating in the world right now.

Linking back to the etymological roots of the curator as caretaker, and to feminist theories of care, I propose that the curatorial as an agent of planetary caretaking happens with and through water. In my doctoral thesis, entitled Ingesting the Hydrocene, I argue that water is both the physical matter and the metaphorical device, that facilitates the curatorial, and that many artists are engaging with water in collaborative manners that aim to decenter anthropocentric world views and usher in collaborative ways of relating to water.

The Hydrocene is a curatorial theory I propose as a new way of naming and defining the zeitgeist of water based art practices that are engaging critically with water, and to see these artistic practices as part of the broader critical water discussions. The Hydrocene argues for artistic methods of thinking with water in the age of accelerating climate crises. Embodied and relational it amplifies unexamined perspectives on the interrelation of curatorial practice, art, climate and water. In the art of the Hydrocene, audiences of these works intimately experience the water crisis as ingested, internal, and embodied through their experience of the artworks. Focusing on the art and artists who bring critical and collaborative water relations to life, the curatorial theory of the Hydrocene articulates, interrogates and argues for contemporary art that collaborates with water and the climate crisis.

This curatorial theory of the Hydrocene is deeply informed by the tide of "watery makers" from the contemporary art field who sense and relate to water in embodied, critical, dialogical and curious manners. These artists think with water and work with water as a collaborative partner. These water-based methods develop critical ways of relating to water in the current climate crisis. The Hydrocene as a curatorial theory connects these practices as a set of interweaving planetary ecologies, which together, demand radical change to current anthropocentric environmentally destructive ways of relating to water.

In developing the Hydrocene as a curatorial theory, I calibrated theorists who have suggested alternative epoch names for our current circumstances, most notably the Anthropocene, but also the Capitalocene or Pyrocene and many others. I was inspired by the pioneering work of Kathryn Yusoff, Sylvia Wynter, Andreas Webber, TJ Demos and Donna Haraway among others, who each critique the naming of Anthropocene. My work 
with the Hydrocene is also inspired by the impressive theoretical push towards working critically with water. Water is the great planetary connector as influential "watery thinker" Astrida Neimanis has written in her groundbreaking book, Bodies of Water. ${ }^{2}$ Similarly, Veronica Strang, Cecilia Chen, Janine MacLeod and Neimanis all call for the recognition that humans literally and metaphorically "think with water" 3 and that water provides a key to learn with and from, both metaphorically and materially, as a substance that is in constant transformation and relation between bodies. I drew also upon astute theories of watery thinking including the work of Elizabeth DeLoughrey "oceanic futures" epistemologies, ${ }^{4}$ Christina Sharpe's book In the Wake: On Blackness and Being, ${ }^{5}$ where the ongoing consequences of slavery are witnessed with water and Stacy Alaimo's dissolving theories of the Anthropocene sea. ${ }^{6}$ Each of these theorists in their own right call for water-based ways of thinking and being.

Engaging with this impressive tide of watery thinkers and theoretical works led me to see that water actually allows

2 A. Neimanis, Bodies of Water: Posthuman Feminist Phenomenology, Bloomsbury Academic, London 2017.

3 C. Chen, J. MacLeod, A. Neimanis, E.G. Trudel (eds.), Thinking with Water, McGill-Queen's University Press, Montreal 2013.

4 E. Deloughrey, Toward a Critical Ocean Studies for the Anthropocene, „English Language Notes" 2019, no. 57, pp. 21-36.

5 Ch.E. Sharpe, In the Wake: On Blackness and Being, Duke University Press, Durham 2016.

6 S. Alaimo, Bodily Natures: Science, Environment, and the Material Self, Indiana University Press, Bloomington 2010. the curatorial to exist. Not only in metaphorical terms, such as circulation and flow, that are often utilized in curatorial practice, but as one of the core substances that animate bodies, and by extension animate the curatorial. Through a deep theoretical engagement with this tide of watery thinkers I discovered that that the curatorial should be understood as a water-based agent, with the capacity to deliver planetary care.

\section{Writing, Teaching, Curating}

When I embarked upon doctoral studies, I was conflicted by the accelerating climate crises. To dedicate four years towards curatorial theory when, as according to the 2018 Intergovernmental Panel on Climate Change (IPCC) report we have a mere 12 years to make radical changes in emissions, to study was a challenging decision and continues to be. I was (and still am) experiencing the waves of grief that Naomi Klein describes in This Changes Everything as part of accepting the climate crises into our bodies. This is an ongoing process, it is a living grief, and for some people it can lead to a condition called "solestalgia," a kind of eco-anxiety.?

Developing ethical relations with what Donna Haraway calls "natureculture," was a priority, and I saw that as

\footnotetext{
"Solestalgia" was named by Australian environmental philosopher Glenn A. Albrecht to capture the distress of losing homelands and is understood as a reversed form of nostalgia, that is a kind of homesickness, G.A. Albrecht, Earth Emotions: New Words for a New World, Cornell University Press, New York 2019.
} 
a curator I have a clear obligation to attempt to develop ethical natureculture relations in the field of art. I set about considering what my research might offer my immediate artistic community but also what it could offer on a planetary scale. I asked myself what knowledges, actions and ideas can I develop and support in my work that will foster ethical and livable futures. Now, in my third year of doctoral studies I attempt to hold the complexities of what an offering of research might be in these difficult times. One way of dealing with these complexities is in making sure my research is shared and carried forward, through the triangulation of writing, teaching and curating. These three ways of working each feed into and support each the other. I see these three elements of my research as intersecting and rejuvenating methods for contributing to the extensive body of knowledge around the climate crises.

In my teaching responsibilities at Stockholm University, I developed classes on Curating in the Climate Crises, where we together confront our internalised and collective fears and desires in answering the question: How to develop and maintain a curatorial practice during the current climate crises? Together we unpack thinking about the ethical, political, social, poetic and aesthetic implications of working curatorially now. I lead the students through artistic and curatorial case studies from contemporary art and the environmental humanities, that incorporate watery thinking, multi-species studies, queer death studies, and activism, among other topics. These examples help us to consider questions such as:
- Whose crisis is it?

- What words do we use and why does it matter?

- How will art stay relevant?

- In which ways will I (or we) contribute?

- Which curatorial strategies offer guidance or illumination?

Teaching is a central method of my research and it guides my understanding of the collective consciousness around the climate crisis in my field. I am grateful for the time I spend with students, whose engaged "thinking-with" always helps to shape my own.

Simultaneous to teaching and writing, I work as a curator with practicing artists. This is a very important part of my methodology for working with the Hydrocene. I keep a close connection to contemporary artists through specific projects or collaborations but also through studio visits, seeing work and exhibitions. Curating is what keeps me connected to the artistic community and is also one of my offerings back to the art field. Examples of the types projects I work on as a curator include a long-term collaboration with artist Signe Johannessen, where for example I join her and the dance company, Cullberg, in developing sensitive water relations informed by bodily experiences of the swamp. In an artist talk I did with Signe Johannessen at Accelerator at Stockholm University, I asked the artist about swamp relations and she answered: "I have this love for the swamp," she describes it as

D.J. Haraway, Tentacular Thinking: Anthropocene, Capitalocene, Chthulucene, „E-Flux” 2016. 
"a closeness." She describes this love again in her piece Letters to a Swamp where she writes: "Ever since you enveloped me for the first time ... I have worked to be able to approach you. You sucked me down into your black water ... Under the surface, over and over again, I find myself possessed." This connection to the swamp is an example of the way the artists who practice Hydrocene aesthetics, such as Johannessen, exemplify ways of building care-based relationships with water, as partners in watery thinking.

Another model is exhibition making, for example in 2020 I curated an exhibition in Madrid, at CentroCentro, with Spanish artist Rosana Antolí with the tag line, Pulse, Throb, Drift. Antolí and I found watery connection through the jellyfish Turritopsis Dohrnii, known as the "immortal jellyfish," which is a creature that can theoretically live forever, as it moves from states of prepubescence to procreation and back again, bobbing along with no natural death built into the life cycle. This jellyfish is a figure Antolí has engaged in her work for many years. As Antolí and her writing collaborator Jano penned in their 2019 manifesto of the immortal jellyfish, "As a symbol of our infinite loop we embrace the Turritopsis Dohrnii ... challenging the transitory of the life, reversing the life cycle and demonstrating to us that it is possible to debunk the most fundamental law of the natural world! This great gelatine consciousness everlasting species..." In my curatorial work with Antolí I introduced watery thinking into our discussions such as Kamau Braithwraite's concept of "Tidalectics" and the associated artistic practices ${ }^{9}$ and the gelatinous writing of Stacy Alaimo on jellyfish and "gelata". ${ }^{10}$ Our curatorial dialogue and the ensuing exhibition went into the deep blue, into the practice of crafting the art of the Hydrocene.

In each of these examples, my work with water and contemporary artistic practice inform each other, as looping, porous experiences, feeding back, like the hydrological cycle itself. In this way, through the connected practices of writing, teaching and curating, I find meaning and purpose in my research within these current urgencies of action.

\section{Missing pieces}

A metaphor for the complexities of researching art during the climate crises comes in the form of Australian author and climate activist Richard Flanagan's striking book, The Living Sea of Waking Dreams. Written in 2020 after catastrophic fires devasted eastern and southern Australia. The story follows Anna, a successful architect who flies in and out from the mainland to the small island Tasmania, to visit her dying mother. In the book Anna and her adult brothers are wound tight into their reality where their elderly and unwell mother must not die. They take extraordinary measures to keep this from happening. The children demand a bargain with death, on their unwilling mothers behalf. Meanwhile

\footnotetext{
9 S. Hessler, Tidalectics: Imagining an Oceanic Worldview through Art and Science, MIT Press, Cambridge 2018.

10 C. Chen, J. MacLeod, A. Neimanis, E.G. Trudel (eds.), Thinking with Water..., op. cit.
} 

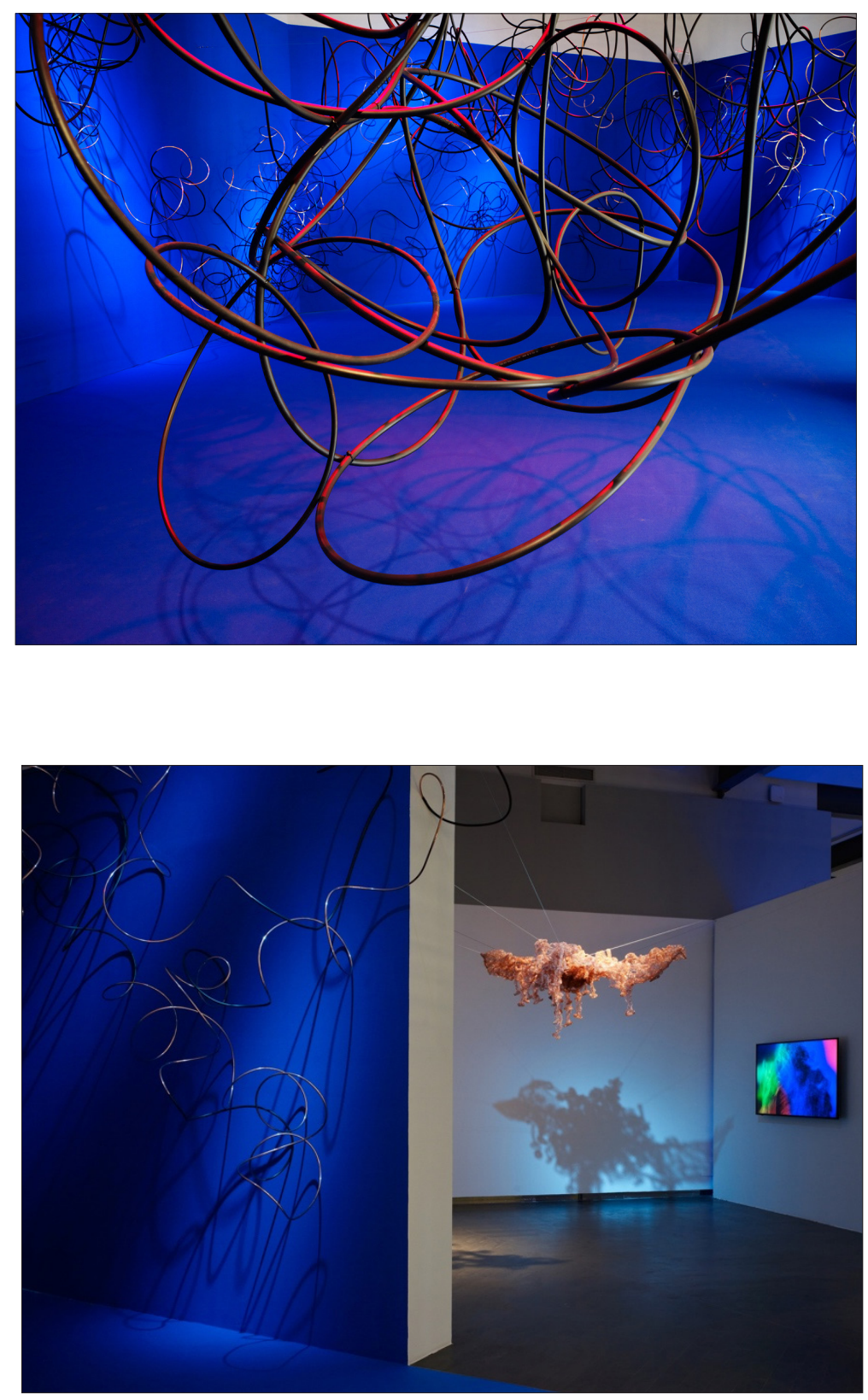


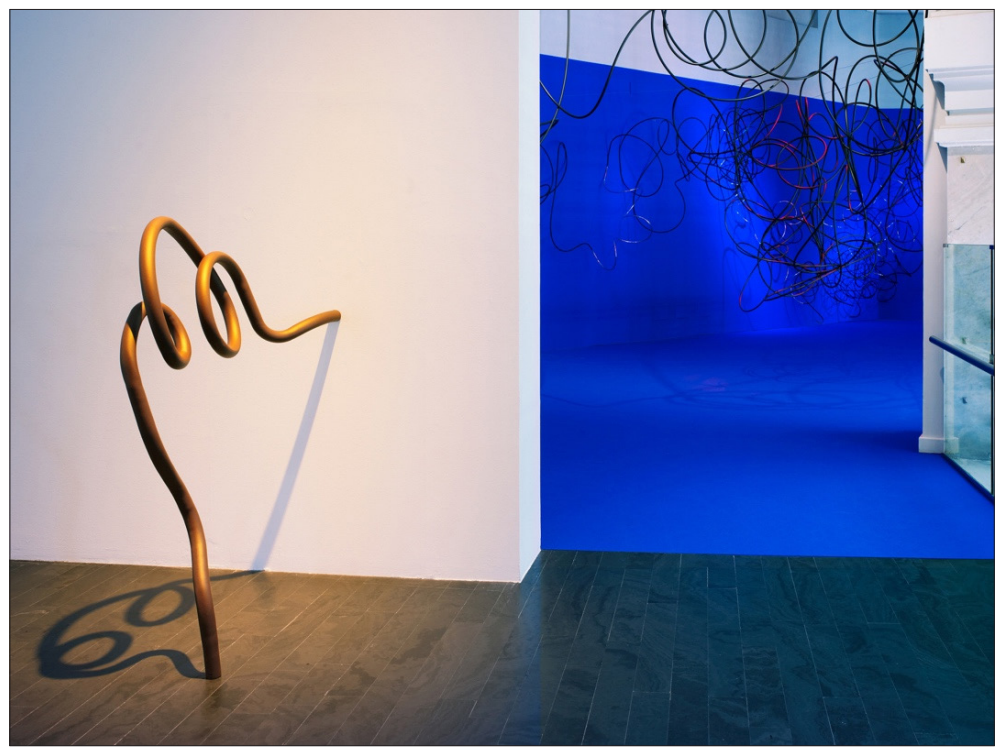

Fig. 1-3. Rosana Antolí, installation view from solo exhibition, A Golden Age: Pulse, Throb, Drift, at CenrtroCentro Madrid, Spain, 2020. Curator: Bronwyn Bailey-Charteris.

Photo credit: Dominik Schulthess

Anna starts to "lose" pieces of herself. First a finger disappears, later a knee, and then more pieces of her seem to evaporate. In their place is simply an absence or an emptiness, that most people do not notice. The story is embedded in the reality of the most recent Australian climate degradation through extreme bushfires and drought. In the saga people flee their homes, ash and smoke flood the city and eerie orange skies greet every new day. Flanagan's story reads allegorically, as a warning, but also as a cry, a moan, a sob.

Just as Anna loses her own body parts, I too sense the heaviness of ecological destruction as embodied. For example, over the European summer of 2020 I was writing about the pioneering work of Tongan/Australian artist Latai Taumoepeau, in particular a startling performance work she made in 2012 entitled I-land X-isle. The live performance version, which I was focusing on, took place outside the Museum of Contemporary Art in Sydney. Outside the museum, the artist was suspended painfully in the air, tied with ropes to a metal structure which held two large ice blocks. As the ice dripped onto the immobilised artist, there were reverberations of the ice caps melting which in turn, through the global movement of water, lead to the inundation of the artists family homelands in the Island Kingdom of Tonga.

As I wrote about Taumoepeau's work over that summer I was also reading the 
latest ground-breaking statistics of the disappearance of ice from the north and south caps, due to incredible global warming. This extinction of ice is rapid and irreversible. ${ }^{11}$ In writing about the complexities of the artists engagement with hydrological cycles, I understood more deeply and in a bodily way, how I too was part of the cycle. In an expanded way the "I" of the researcher, who has traditionally been seen as separate and impartial, was, through thinking with water, deeply implicated in all of this. The "I" of my person became porous as I moved between the states of research. Knowing about all the symptoms of our sickly planet: the death of the oceans, the extinction of the ice, the burning rainforests, micro plastics everywhere, all-consuming toxicity, and the way each of these intersect and are enforced by environmental racism, exploitation, colonialism and extractivism, it is easy to be consumed in a deep climate grief or stunned into a silent disbelief.

In researching and developing the Hydrocene I am like the character of Anna from Flannery's book. I too lose parts of myself in the process. I attempt to confront the disappearing acts of my own and others bodies, both more-than-human and human, along with the incalculable loss of homes, lives and cultures. These are pieces disappearing, never to

11 E. Hanna, J. Cappelen, X. Fettweis, S.H. Mernild, T.L. Mote, R. Mottram, K. Steffen, T.J. Ballinger, R. Hall, Greenland Surface Air Temperature Changes from 1981 to 2019 and Implications for Ice-sheet Melt and Mass-balance Change, „International Journal of Climatology" 2020. return or sometimes radically transforming, never to be the same.

\section{Hydrologics as Methodology}

In understanding the Hydrocene as a curatorial theory, I developed criteria for the works I am engaging. To begin with the Hydrocene looks to currently practicing artists and curators, working in the contemporary field, with a long-term commitment to working with water, both materially and metaphorically. Alongside a long-term commitment to water the works which illustrate the Hydrocene engage with qualities of Neimanis' concept of hydrofeminism and have a direct link to examinations of the climate crisis, for example sea levels rising or environmental racism. Hydrocene as curatorial theory has as a special focus on bodies experiencing climate through processes such as performance, performativity or embodiment. Finally, the works must utilise a kind of "hydro-logic" in their work, that they collaborate and think with water.

I aim to use the logic of water as a basis for the research methods. This is inspired by the artists, where I see that the methods they employ are often hydrological, for example, many of the works in the ice chapter deal with melting or what I call "unfreezing." I then develop a research method of "unfreezing" as a way to curatorially conceptualise the works. I learn from the water to learn about these works about water. 
The Hydrocene recognises water as having agency ${ }^{12}$ and is a practice of situated knowledge production, ${ }^{13}$ and while the art of the Hydrocene can be mapped internationally across artistic practices, it is important to remember all waters are situated and relational. ${ }^{14}$ I look to where this publication is based, in Poland, and to the artists and watersheds who sustain them. This issue of Arts \& Cultural Studies Review is evidence of the cultural push into the blue currently happening in Poland and the Hydrocene can be recognised here.

\section{Rivers of the Hydrocene}

In this section I will follow one stream of the Hydrocene, mainly following rivers, that begin in Poland, travel to Norway, Sweden, Finland, Estonia, New Zealand, Columbia and back to the north of Norway. This is one of many streams of the Hydrocene. Let's begin in Poland where the river is home to a mythical water nymph. Artist Justyna Górowska takes a new path where the water nymph moves into techno-waters, with the cyborgian Wet Me Wild. With a mix of VR and performance, the artist captures the conflicted contemporary mythologies of water in a technology fueled age. Further down the river, art and activism take over in the Polish collective, Sister Rivers, led

12 C. Chen, J. MacLeod, A. Neimanis, E.G. Trudel (eds.), Thinking with Water..., op. cit.

13 D.J. Haraway, Situated Knowledges: The Science Question in Feminism and the Privilege of Partial Perspective, „Feminist Studies” 1988, vol. 14 (3), pp. 575-599.

14 A. Neimanis, Bodies of Water..., op. cit. by artist Cecylia Malik. Together they use performance actions to defend the rivers of Poland from pollution and development. These trends towards water are also evident in the region where I am based, in Sweden and the Nordic. The river as a site of activism is especially present in the northern regions where the intersection of mining, hydroelectricity and damming impact Indigenous and non-Indigenous communities, and the other more-than-human species who live there. Notably the touring exhibition from Office for Contemporary Art Norway, entitled Let the River Flow: The Sovereign Will and the Making of a New Worldliness shared the work of Sami artists and activists and Indigenous led resistance to the damming of Álttáeatnu (Áltá river) in Sápmi, Northern Norway. Following the river, in the video work of Swedish artist Anja Örn, who lives and works in Luleå in the north of Sweden, her video work entitled, In Memory of a River, takes a personal narrative through the archives of the lost waterfalls of the region, which have now been diverted for hydroelectricity. In a symbolic exchange, the majesty of the water in the north is sent south to major cities and centres of power. Nordic river works across the border in Finland are found in Helsinki based artist Kati Roover, who has investigated rivers from an emotional, geographical and watery lens. The final video work, produced after years of research, is entitled Do rivers really ever end? It begins with a handheld image of the Võhandu river in Estonia running over the artist's feet. In a whispered tone she tells the camera, this is the river her mother visited when she was pregnant: it 
flows through her and through the baby in the artist's womb. The river cycles through generations. The opening scenes of the film pulse with embodied hydrofeminism, and there is a sense of watery beings, reaching through time, with permeable skins.

Later in the video work the artist films the river Whanganui in New Zealand, where the sacred river gained legal status as personhood. The case was fought and won by Maori activists over seven years and this historic case has led to similar legal challenges for the rights of water bodies to be recognised with personhood in Columbia, Sweden and other places.

Both the Whanganui in New Zealand and the Álttáeatnu (Áltá river) in Sápmi Northern Norway are examples of Indigenous led resistance and climate activism, which are central to thinking with water and the Hydrocene. Thinking with water is integral to many First Nation scholarships and cosmologies, for example "Water is Life" is the chant of the Lakota water defenders against invasive pipelines and Sto:Loh nation poet and author Lee Maracle reminds us in the essay "Water" that The water owns itself..$^{15}$ Indigenous scholarship and cosmologies of water are something I am still learning with and about. As a white researcher I am humbly aware of the complexities of this situation, and the direct link between the climate crisis and racism and colonialism. I am in the ongoing learning process of seeing

15 D. Christian, R. Wong, Downstream: Reimagining Water, Wilfrid Laurier University Press, Waterloo-Ontario 2017. where decolonial water practices in my research can emerge.

Following the tracks of the river in the Hydrocene, the work of Daniel Torres, in the online exhibition Take me to the River, offers a poignant assessment of the exhaustion of the rivers. The artist's film work Superficies looks at the Atrato River in Columbia, and at one stage has a black and white image with a polluted river bank with a voice over: If I were the river, I would feel tired. To follow exhaustion and water, we return to the north, and come to the writing of the sleeplessness of the sea as written about by Astrida Neimanis in her essay, So Tired, the Sea which she presented at the 2019 edition of the Lofoton International Art Festival (LIAF) in northern Norway. In the text Neimanis, the feminist phenomenologist who coined the term "hydrofeminism," speaks of ice caps melting and the Amazon burning and yet, "no matter how hard we gather, we cannot press a pleat into the planet's surface, so that the now gushing glacial waters might connect with that scorched earth to sooth it" (H. Mehti, N. Cahoon, and A. Wolfsberger 2020). At the same edition of LIAF, during the Kelp Congress, artist Signe Johannessen, with whom I collaborate on the swamp beings, presented her work the Kelp Medal of Honour. The artist made the delicate medal in the town of Lofoton with local participants. Later in the festival the artist and the community participants proceeded down the main street with flags and banners, a procession to present the medal to kelp. The macro-algae kelp was honoured for saving the life of Norwegians fleeing the German Nazi soldiers 

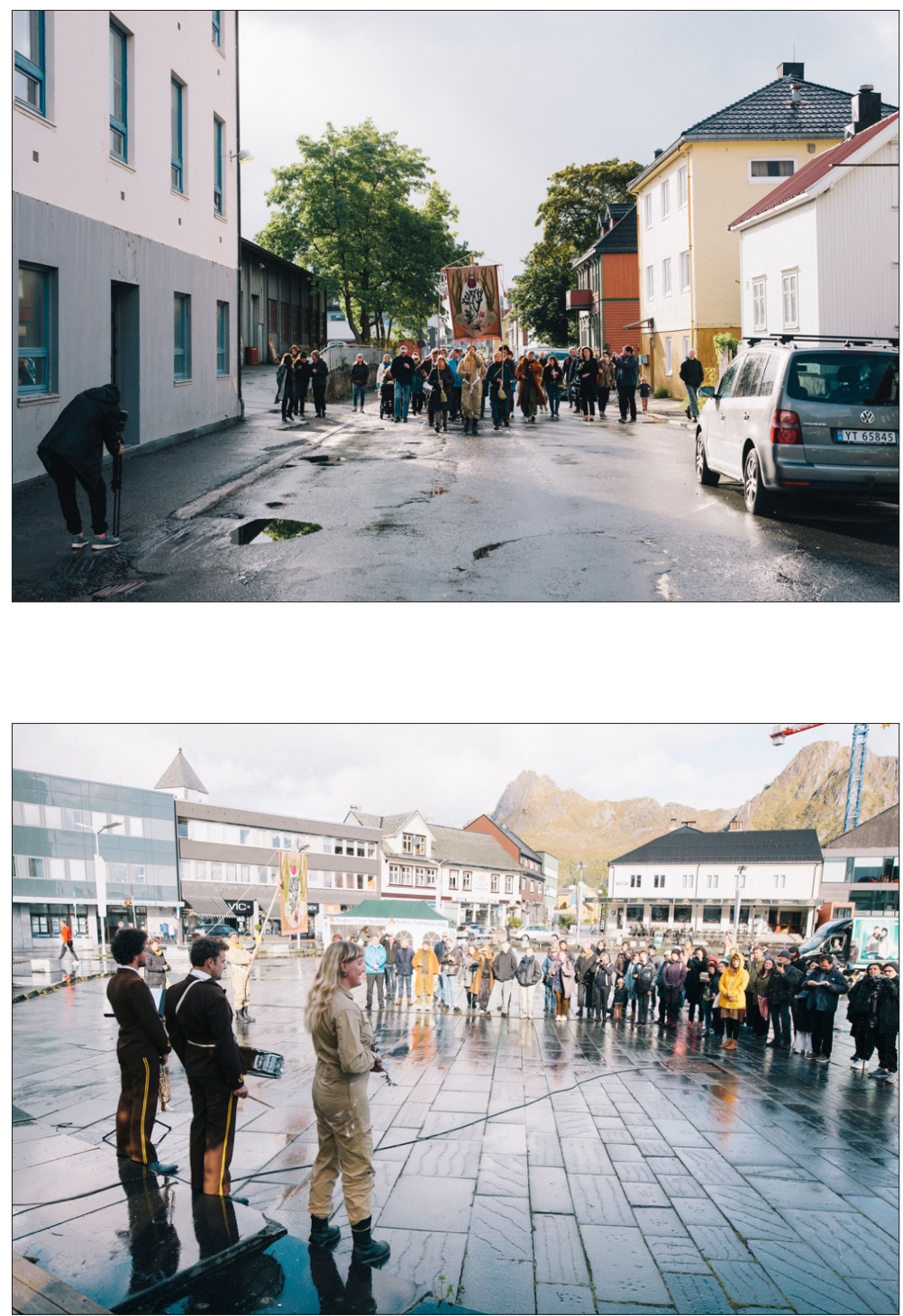


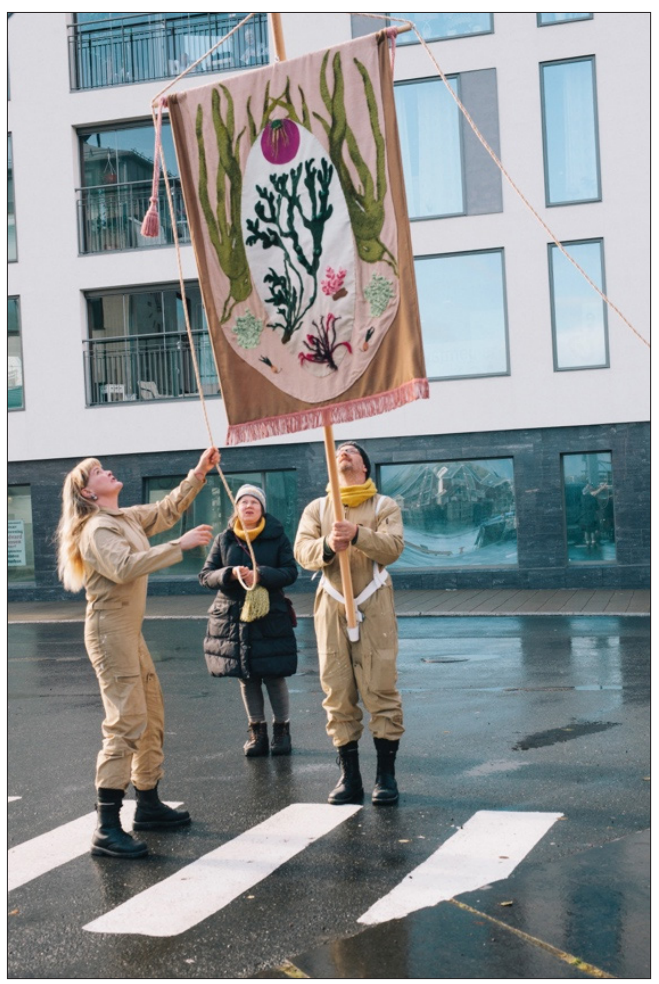

Fig. 4-6. Signe Johannessen, performance documentation, Kelp Medal of Honour, presented at Lofoton International Art Festival (LIAF), Norway, 2019. Photo credit: Michael Miller

during WW2, including some ancestors of the artist herself, who hid in the kelp to hide from soldiers during the war. In each of these works there is the capacity for watery thinking, and for finding ways to collaborate empathetically with water.

I could go on. This is one stream, of many. The waters are always returning. Together these examples are an elucidation of the Hydrocene as a watery web of connection between bodies of water in art.

My research remains embodied, at times conflicted, but I know where it is and it is a hopeful act. The Hydrocene plays out in the waters, in the splashing intersection of art, water and climate as deeply interconnected to questions of poetics, politics and hydrologics and ultimately to the development of new strategies of curatorial caretaking for a planet that is dying.

\section{A pool of research}

To end these watery reflections I will share my internal image for my process of researching art, water and the climate 
crisis. It's an image of a beach in Sydney. It's sunny and I am standing waist deep in cool green waters with sand under my toes. Gentle waves pass around me. I can see both the shoreline and the horizon. I am half submerged, between land and sky, in the waters. My research is the process of cupping water from the ocean in my hands. I can never pick up the whole ocean in my hands, and yet I keep trying. The water is desperate to return to the ocean below: it consistently drips, fingers reveal leaks and quickly it becomes relational between bodies of water. And while the waters are struggling to return to the ocean, my hands form a pool, just for a moment. This pool in my hands is the research. The temporary pool becomes a tangible zone for observation, contemplation and water-based ontology. Each pool I form in my hands is made with "natureculture," not separate to it. Integral to each pool are the artists and the water, who relate to each other in it. As I peer into my hands, I recognize that each pool holds its own rhythm, cadence and memories. As the researcher, I am holding pools in my hands, and my role is to pay deep attention, notice the points of connection and in this manner, define a temporality and location for each pool, as separate and also infinitely connected.

In this way, through scooping the waters into my hands, the Hydrocene revealed itself to me. Through the intersecting urgencies of artists' practices and crumbling climates, I have become highly tuned to artistic collaborations with water. Water is my inner hook for understanding these ways of making planetary points of connection in art. I stand between land and sky, in the water, and form a counterbalance, with the rapid climate crises at one end and the radical potential of art making at the other. Led by the artists and the water, the Hydrocene glistens in the pool of my hands.

\section{Bibliography}

Alaimo S., Bodily Natures: Science, Environment, and the Material Self, Indiana University Press, Bloomington 2010.

Albrecht G.A., Earth Emotions: New Words for a New World, Cornell University Press, New York 2019.

Chen C., MacLeod J., Neimanis A., Trudel E.G. (eds.), Thinking with Water, McGill-Queen's University Press, Montreal 2013.

Christian D., Wong R., Downstream: Reimagining Water, Wilfrid Laurier University Press, Waterloo-Ontario 2017.

Deloughrey E., Toward a Critical Ocean Studies for the Anthropocene, „English Language Notes" 2019, no. 57, pp. 21-36.

Fischer C., Dolezal L. (eds.), New Feminist Perspectives on Embodiment, Palgrave Macmillan, New York 2018.

Hanna E., Cappelen J., Fettweis X., Mernild S.H., Mote T.L., Mottram R., Steffen K., Ballinger T.J., Hall R., Greenland Surface Air Temperature Changes from 1981 to 2019 and Implications for Ice-sheet Melt and Mass-balance Change, „International Journal of Climatology" 2020.

Haraway D.J., Situated Knowledges: The Science Question in Feminism and the Privilege of Partial Perspective, „Feminist Studies" 1988, vol. 14 (3), pp. 575-599.

Haraway D.J., Staying with the Trouble: Making Kin in the Chthulucene, Duke University Press, Durham 2016.

Haraway D.J., Tentacular Thinking: Anthropocene, Capitalocene, Chthulucene, „E-Flux” 2016. 
Haraway D.J., The Companion Species Manifesto: Dogs, People, and Significant Otherness, Prickly Paradigm Press, Chicago 2003.

Hessler S., Tidalectics: Imagining an Oceanic Worldview through Art and Science, MIT Press, Cambridge 2018.

Neimanis A., Bodies of Water: Posthuman Feminist Phenomenology, Bloomsbury Academic, London 2017.

Neimanis A., Hydrofeminism: Or, on Becoming a Body of Water [in:] H. Gunkel, Ch.
Nigianni, F. Söderbäck (eds.), Undutiful Daughters: Mobilizing Future Concepts, Bodies and Subjectivities in Feminist Thought and Practice, Palgrave Macmillan, New York 2012, pp. 96-115.

Sharpe Ch.E., In the Wake: On Blackness and Being, Duke University Press, Durham 2016.

Wong R., Mochizuki C., Undercurrent, Nightwood Editions, Gibsons, Canada 2015. 